\title{
The Impact of Managerial Entrenchment Indicators on Cash Holding Adjustments: Stock Exchange Firms
}

\author{
Zahra Hashemi Oskouei \\ Department of Accounting, East Tehran Branch, Islamic Azad University \\ Tehran, Iran \\ Tel: 98-912-381-6127Ｅ-mail: zahra.oskouei@gmail.com \\ Zeynab Aminifard (Corresponding author) \\ Department of Accounting, East Tehran Branch, Islamic Azad University \\ Tehran, Iran \\ Tel: 98-912-359-7243Ｅ-mail: aminifard.zeynab@gmail.com
}

\begin{abstract}
Received: April 8, 2019 Accepted: June 12, $2019 \quad$ Published: June 12, 2019
doi:10.5296/ajfa.v11i1.14805 URL: https://doi.org/10.5296/ajfa.v11i1.14805
\end{abstract}

\begin{abstract}
This paper investigates the relationship between the managerial entrenchment and cash holding adjustments for a sample of 140 firms listed in the Tehran Stock Exchange (TSE) during 2011 to 2016. To measure the managerial entrenchment, four indicators of manager's duality, management reward, dividends, and over-investment risk were employed. A multiple linear regression model was used in order to test the hypotheses of the research. The results indicate that when management rewards were used to measure the managerial entrenchment, there is a significant positive relationship between the management rewards and cash holding adjustments. Also, there is a significant positive relationship between the over- investment risk and cash holding adjustments. Cash holding speed was found to have a significant positive effect on the relationship between dividend (managerial entrenchment) and cash holding adjustments. These results suggest a significant positive relationship between the managerial entrenchment and cash holding adjustments.
\end{abstract}

Keywords: Cash holdings, Cash holdings speed, Managerial entrenchment, Over-investment risk, Management reward 


\section{Introduction}

The main advantage of cash holding is to increase the capability of a firm based on valuable investment opportunities, and to prevent costly external financing (Jiang \& lie, 2016). Focusing on the various dimensions of cash, Dittmar \& Smith (2007) demonstrated that cash and near cash comprise $13 \%$ of the total American firms' assets in average. Also, Habib et al. (2017) indicates the presence of $6 \%$ cash in the total assets of UK firms. Since all firms with unbalanced cash face many problems, it is important to investigate the amount of cash holding deviation and how rapidly their cash moves towards its own target level (Titman \& Wessels, 1988). One of the early studies on cash holdings was performed by Kim et al. (1998) focusing on the firms' investment decisions in cash assets when the cost of external financing is high. They believed that optimal cash amount is determined by balancing of low return of cash assets and the profit obtained by minimizing the needs to external financing (Bates et al., 2009). The early studies of cash holdings investigated only the factors that influence cash holdings and the effect of firms' special features and their environment on cash holdings. These studies rarely considered that how quickly firms move their own cash towards the optimal level. The research by Opler et al. (1999) is one of the first studies carried out about partial adjustment. The study of Ozkan \& Ozkan (2004) about determining the level of cash holdings in UK firms estimated the optimal holdings level using a dynamic trade-off model. Their study could indirectly attract attentions towards cash adjustment speed (Al-Dhamari \& Ismail, 2014). It is essential to study managerial entrenchment and cash holding adjustments because of three reasons including: (1) more studies are needed for various firms and countries; (2) for firms encountering unbalanced cash, it is important to investigate the amount of cash holding deviation, and to study how quickly the cash moves towards its own target level; and (3) understanding the factors that play a role in cash holding adjustments not only keeps the investors' profits but also causes the growth and development of the firm. Finally, it increases profitability and provides shareholders' satisfaction in terms of excess cash holding policies in the firm.

Very few studies have been carried out about the factors influencing cash holding adjustments in Iranian firms. The present study aims to investigate the relationship between the managerial entrenchment and cash holding adjustments for 140 Iranian firms from the Tehran Stock Exchange (listed from 2011 to 2016). This research aims to address the main question as whether managerial entrenchment can result in cash holding adjustments for this sample of firms through analyzing the data and observations of firm-year (140 firms in 6 years).

\section{Theoretical bases and hypotheses}

Firms usually maintain considerable amounts of cash in their balance sheets because of capital market failures such as asymmetric information, problems of representation, transaction costs and financing costs (Locorotondo et al., 2014). Although cash holding is taken into account as an important asset for a firm in their balance sheet, maintaining this asset excessively indicates inefficiency of resources allocation, and it involves some costs for the firm (Subramaniam et al., 2011). These costs may involve the cost of capital opportunity, external financing costs and representative costs in relation to supervision. Bates et al. (2009) and Ferreira \& Vilela (2004) 
studied the ratio of cash to all assets of the European Monetary Union firms and concluded that these firms maintained $15 \%$ of the total assets in the form of cash or near cash. Also, Bates et al. (2009) reported that the average ratio of cash to the assets of the US industrial firms increased by $129 \%$ from 1998 to 2004 . At last, managers must decide whether the cash should be distributed among shareholders, it should be allocated to internal expenditures or it should be maintained. They should always evaluate the benefits and losses of their decision. One of the most important factors of high cash holdings is asymmetric information and its problems (Supbramanian et al., 2011). Francis et al. (2004, 2005) and Ozkan \& Ozkan (2004) reported that firms are motivated to maintain high cash assets because of increasing asymmetric information. In other words, asymmetric information results in increasing the capital cost, and providing the costs from financial markets is not beneficial for firms. Hence, firms prefer to maintain more cash assets so that they can provide their required cash from internal resources when necessary. This theory is based on the hypothesis that those working inside a firm are more aware than shareholders. If internal resources of a firm are not sufficient for financing of optimal investment programs, and asymmetric information becomes an obstacle, then the managers may be forced to ignore profitable projects. In this case, cash becomes very valuable. The opportunity to issue the shares without losing the market value is provided when there is no asymmetric information or very less asymmetry. Therefore, managers prefer cash holdings so that they can provide financing from inside the firm in the first step (Ferreira \& Vilela, 2004). In the present research, it is predicted that adjustment speed reflects three main factors including: (1) deviation value of the objective ratio; (2) value of cash adjustments; and (3) manager's tendency in cash adjustments. The deviation value of the objective ratio includes the costs of financial crisis and over investment. When this optimal ratio is low, managers quickly try to compensate cash shortage (Jiang \& lie, 2016). In addition, it is anticipated that financial risks and operational risks affect adjustment speed. In contrast, there are some competitive hypotheses investigating the interest of managers in cash adjustment speech. Opler et al. (1999) believe that managers tend to maintain excess cash because they do not want to take any risk, and they prefer to follow their own objectives. This issue prevents from using the cash timely or paying cash reservoirs to maximize the cash when there is no external pressure. Therefore, we should follow high cash adjustments among the firms. On the other hand, Jensen (1986) believes that managers are interested in inefficient cash investment because even the projects with negative net present value have some profit for them, thus these managers may prefer excess investment.

According to Richardson (2006), entrenchment is analyzed from two perspectives. The first one is the managerial entrenchment related to all behaviors resulting in keeping the job, increasing decision-making freedom and maintaining personal profits. The second one is the shareholder entrenchment. This kind of entrenchment is considered either as a demolition tool when high costs are enforced for the firm and the firm investments are inefficient; or as a desirable tool when the firm survival is possible, and it is related to the firm growth. Jensen (1986) infers that when there are excessive cash resources, managers would behave in an optimistic manner and they would probably invest in projects with negative net present value to receive more rewards. This can result in losing the firm resources. Harford et al. (2008) 
argues that large and well-known firms try to control their own cash reserves because they believe that these excessive resources can unwantedly attract the attention of individuals. Lee \& Lee (2009) investigated negative effects of cash holdings on firm's value. A linear regression model was used to test the research hypotheses. They concluded that the negative effects of excess cash and the manager violations to the firm values could be controlled and adjusted by a strong board of directors.

Jani et al. (2004) studied the relationship between conservatism and cash holdings in American firms during 2005-2009 using linear regression methods. They concluded that accounting conservatism had relation with efficient use of cash holdings. This shows that accounting conservatism can be considered as a replacement for external supervision in firms, and it can reduce representative conflict costs between the managers and shareholders. Gul \& Tsui (2012), in a study on American firms during 2006-2010, investigated the effects of firms' credit rating on cash holdings. They found out that the firms with reduced credit ranking, in comparison to the firms without any changes of credit ranking, took actions to increase $3 \%$ of cash holdings in relation to the total non-cash assets. Locorotondo et al. (2014) investigated the business group companies and cash holding level in Belgian firms (those accepted in Belgian stock exchange during 2010-2012). They showed that cash holding level was lower in the firms that were the member of commercial and business groups in comparison to independent firms.

Jiang \& Lie (2016) investigated the relationship between cash holding adjustments and managerial entrenchment in Chinese firms during 2008-2014. They used a linear regression model and Ozkan \& Ozkan's method to test the hypotheses. They reported that the firms covered $31 \%$ of the gap between the ratio of real cash to target cash (the ratio of target cash) each year. Generally, cash ratio adjustment occurs quickly when the ratio of real cash is greater than the ratio of target cash. The reason may be that reduction in cash is cheaper than increase in cash. When the firms become more impervious against takeover threats, they considerably decrease their cash adjustments in high cash ratios. Evidence shows that managers who seek benefits do not tend to distribute surplus cash; and they tend to hold cash in high levels except in cases when the firms are under external pressures.

\subsection{Research hypotheses}

The first main hypothesis studied in the present paper is: managerial entrenchment has a significant effect on cash holding adjustments. The second main hypothesis is: the speed of cash holdings has a significant effect on the relationship between managerial entrenchment and cash holding adjustments. The sub-hypotheses include:

The first sub-hypothesis: the manager's duality (managerial entrenchment) has a significant effect on cash holding adjustments.

The second sub-hypothesis: the management reward (managerial entrenchment) has a significant effect on cash holding adjustments.

The third sub hypothesis: dividend per share (managerial entrenchment) has a significant effect on cash holding adjustments. 
The fourth sub-hypothesis: over-investment risk (managerial entrenchment) has a significant effect on cash holding adjustments.

The fifth sub-hypothesis: the speed of cash holdings has a significant effect on the relationship between the manager duality (managerial entrenchment) and cash holding adjustments.

The sixth sub-hypothesis: the speed of cash holdings has a significant effect on the relationship between the management reward (managerial entrenchment) and cash holding adjustments.

The seventh sub-hypothesis: the speed of cash holdings has a significant effect on the relationship between dividend per share (managerial entrenchment) and cash holding adjustments.

The eighth sub-hypothesis: the speed of cash holdings has a significant effect on the relationship between over investment risk (managerial entrenchment) and cash holding adjustments.

\section{Methodology}

\subsection{Data description}

For this study, a sample of firms accepted in the Tehran Stock Exchange (TSE) during 20112016 was analyzed. The following criteria were employed to screen and select the firms for investigation: (1) the acceptance date for the firm to be listed in the stock must be before 2011 and until the end of 2016; (2) the required information and data must be available, and dividends have been done continuously; and (3) the end of fiscal year is end of March, and during the period of investigation, fiscal year has not changed. These criteria resulted in 140 firms to be selected for the study over the period of 2011-2016. Totally, 840 observations (firmyear) needed to be tested. The data and audited information of these firms were collated and investigated by the panel data multiple regression. The data were extracted from Rahavard Novin Software (Iran's stock exchange databases), and were combined with their financial statements. EViews software was employed to analyze the data and information.

\subsection{Data analysis and research variables}

In this study, the model of Jiang \& lie (2016) was used to test the research hypotheses. To test the first hypothesis, the relationship between managerial entrenchment and cash holding adjustments is investigated; and to test the second hypothesis, the intervening effect of cash holdings speed on the relationship between managerial entrenchment and cash holdings adjustments is studied for the selected firms. To do this, models (1) and (2) were used for the first and second hypotheses, respectively:

$$
\begin{aligned}
& \operatorname{Cash}_{\mathrm{it}}-\mathrm{Cash}_{\mathrm{it}-1}=\lambda\left(\operatorname{Cash}_{\mathrm{it}}{ }^{*}-\mathrm{Cash}_{\mathrm{it}-1}\right)+\beta_{1}\left(\mathrm{Cash}_{\mathrm{it}}{ }^{*}-\mathrm{Cash}_{\mathrm{it}-1}\right) \times \text { Entrenchment }_{\mathrm{it}}+\beta_{2}\left(\mathrm{Cash}_{\mathrm{it}}{ }^{*}-\mathrm{Cash}_{\mathrm{it}-1}\right) \times \\
& \text { Control Variable }{ }_{i t}+\varepsilon_{\text {it }} \\
& \text { Model (1) }
\end{aligned}
$$




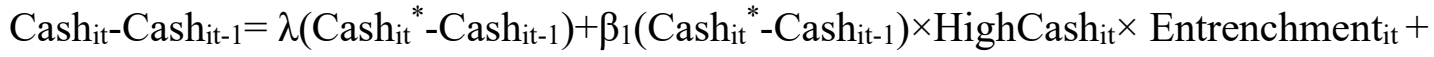

$$
\begin{aligned}
& \beta_{2}\left(\mathrm{Cash}_{\text {it }}{ }^{*}-\mathrm{Cash}_{\mathrm{it}-1}\right) \times \text { Control Variable }_{\text {it }}+\varepsilon_{\text {it }}
\end{aligned}
$$

where the operational definition of variables is as follows:

\section{Dependent variable and the method of computation}

Cash holding adjustment: the model of Ozkan \& Ozkan (2004) was used to compute cash holding adjustments:

$$
\operatorname{Cash}_{\mathrm{it}} \mathrm{Cash}_{\mathrm{it}-1}=\lambda\left(\mathrm{Cash}_{\mathrm{it}}{ }^{*}{ }^{-} \mathrm{Cash}_{\mathrm{it}-1}\right)+\varepsilon_{\mathrm{it}}
$$

Cash $_{\text {it }}$ is the ratio of real cash to book value of assets in year $t$.

$\mathrm{Cash}_{\mathrm{it}}{ }^{*}$ is the target cash in year $t$ that is equal to moving average of cash during past five years to the book value of assets in year $t$.

$\mathrm{Cash}_{\mathrm{it}}{ }^{*}-\mathrm{Cash}_{\mathrm{it}-1}$ is the deviation from the target level of cash in year $t$.

$\lambda$ is the adjustment coefficient indicating the speed towards the target level.

HighCash $_{\text {it }}$ is a dummy variable. It is equal to 1 if $\mathrm{Cash}_{\mathrm{it}}$ is larger than $\mathrm{Cash}_{\mathrm{it}}{ }^{*}$; otherwise, it is equal to zero.

\section{Independent variable and the method of computation}

In this research, managerial entrenchment (Entrenchment $\left.{ }_{i t}\right)$ was an independent variable. To measure the managerial entrenchment, four indicators of manager's duality, management reward, dividends, and over- investment risk were employed.

1) Manager's duality (DUALITY it) is measured as a dummy variable. If the manager is simultaneously both managing director and manager, then it is equal to 1; otherwise, it is equal to zero.

2) Management reward (REWARD $D_{\mathrm{it}}$ ) is equal to natural logarithm of 1 and the managers reward in firm $i$ in year $t$.

3) Dummy variable of dividends: (DUMMY_DIV $V_{\mathrm{it}}$ ): If firm $i$ divides the profit in year $t$, it receives 1; otherwise, it receives zero.

4) Over-investment risk (Over-Investment_Risk $\mathrm{i}_{\mathrm{it}}$ ): In order to compute excess-investment risk, Model (4) was used. For this purpose, investment efficiency should be obtained using Model (4).

$$
\mathrm{INV}_{\mathrm{it}}=\beta_{0}+\beta_{1} \mathrm{Q}_{\mathrm{it}-1}+\varepsilon_{\mathrm{it}}
$$

Investment $\mathrm{it}_{\mathrm{it}+1}$ is the amount of investment in capital assets in year $t$ (equals the capital costs in year $t$ ).

$\mathrm{Q}_{\text {it-1 }}$ is equal to QTOBIN ratio in year $t$ : the ratio of market value of total assets (the market value of assets is equal to the capital market value plus the book value of debts) / book value of assets in firm $i$ in year $t$. 
$\varepsilon_{i t}$ : Absolute value with high regression error shows investment efficiency. Generally, the smaller the absolute value of errors, the higher investment efficiency and vice versa. Then, firms should be divided into two classes including over-investment and under investment. For this purpose, the median of absolute value with high regression value should be computed. The firms located above the second quarter (median) are categorized as over-investment firms, and others as under-investment. At last, we used one dummy variable. A dummy variable is a variable receiving the value of one or zero. The firms with over investment receive one, and others receive zero.

\section{Moderator variable}

In this research, the speed of cash holdings $\left(\right.$ HighCash $\left._{i t}\right)$ is a moderator variable. To measure this variable, we used one dummy variable which is equal to 1 if $\mathrm{Cash}_{\mathrm{it}}$ is larger than $\mathrm{Cash}_{\mathrm{it}}{ }^{*}$; otherwise, zero.

\section{Control variables and the method of computation}

1. The size of firm (SIZE $\left.E_{i t}\right)$ The variable of the firm size is equal to the natural logarithm of total assets value of firm $i$ in year $t$.

2. (QTOBIN $\mathrm{Nit}_{\text {) }}$ is equal to the ratio of market value of total assets (the market value of assets is equal to the capital market value plus the book value of debts) / book value of assets in firm $i$ in year $t$.

3. Operational cash flow risk $\left(\mathrm{CFV}_{\text {it }}\right)$ : It is the standard deviation of operational cash flow related to the past five years of firm $i$ in year $t$.

4. Net working capital ( $\mathrm{NWC}_{\mathrm{it}}$ ) is equal to the ratio of working capital (that is equal to current assets minus current debts) divided by the total assets in year $t$.

5. Financial leverage $\left(\mathrm{LEV}_{\mathrm{it}}\right)$ : The index of financial leverage of firm $i$ in year $t$ is equal to the ratio of debts to assets.

6. The age of firm $\left(\mathrm{AGE}_{\mathrm{it}}\right)$ : The variable of firm's age is equal to the age of firm since its establishment.

\section{Results and Discussion}

Descriptive statistics for the research variables are presented in Table 1 indicating descriptive parameters for each variable separately. These parameters are commonly related to central indices such as minimum value, maximum value, mean, median as well as dispersion indices such as standard deviation. The most important central index is the mean value which shows the balance point and center of distribution gravity, and it is a suitable index to show data centrality. The mean and median cash holding level were 0.053 and 0.032 , respectively with minimum and maximum values of 0.0006 and 0.515 , respectively. This indicates that the cash amount and short-term investment of the firms is about $5 \%$ of their assets.

The mean cash holding level in the previous year is about 0.054 which shows that the amount of cash holding has reduced in comparison to the previous year. Also, standard deviation of cash holding level in the previous year is about 0.067 , which has increased about 0.002 in comparison to the standard deviation of cash holding in the current year $(0.065)$. It shows that 
the liquidity risk has increased. Also, the mean and median optimal cash holdings are respectively 0.056 and 0.041 with minimum and maximum values of 0.002 and 0.427 , respectively.

By comparing the mean cash holdings in the current year (0.053), and the mean target cash holdings (0.056), it can be said that the studied firms had a distance with their target cash holdings. The mean and median values of manager's duality were 0.078 and 0.000 , respectively with minimum and maximum values of 0 and 1, respectively. This shows that in about $8 \%$ of the studied firms, the general manager was the chief executive officer (CEO) too, and this low percentage is related to the stock exchange suggesting to firms not to have the same general manager and CEO. Also, the mean (standard deviation) logarithm of manager reward is 2.450 (3.340). This shows that the logarithm of auditing fee is 2.450 . The high standard deviation of 3.340 shows large variations in auditing fees among the auditing companies. Dummy variable mean dividends was found as 0.963 , and its median is 1 . This shows that $96 \%$ of the studied firms pay cash profit (paying cash profit and its statement during cash flow). The reason of cash profit payment is the necessity of stock exchange to pay dividends. The mean and median over-investment risk were 0.500 and 0.500 , respectively. This shows than over half of the studied firms had over-investments. 
Table 1. Descriptive statistics of research variables.

\begin{tabular}{|c|c|c|c|c|c|}
\hline Variable & Mean & Median & $\begin{array}{l}\text { Standard } \\
\text { deviation }\end{array}$ & Minimum & Maximum \\
\hline Cash holding level $\left(\mathrm{CASH}_{\mathrm{it}}\right)$ & 0.053 & 0.032 & 0.065 & 0.0006 & 0.515 \\
\hline $\begin{array}{c}\text { Cash holding level of previous } \\
\text { year }\left(\mathrm{CASH}_{\mathrm{it}-1}\right)\end{array}$ & 0.054 & 0.033 & 0.067 & 0.0006 & 0.515 \\
\hline $\begin{array}{c}\text { Optimal cash holding level } \\
\left(\mathrm{Cash}_{\mathrm{it}}{ }^{*}\right)\end{array}$ & 0.056 & 0.041 & 0.052 & 0.002 & 0.427 \\
\hline $\begin{array}{c}\text { Deviation of optimal cash } \\
\text { holding level } \\
\left(\text { Cash }^{*}{ }^{*}-\mathrm{CASH}_{\mathrm{it}-1}\right) \\
\end{array}$ & 0.001 & 0.004 & 0.047 & -0.331 & 0.180 \\
\hline $\begin{array}{c}\text { Cash holding speed (HIGH } \\
\left.\text { CASh }_{\text {it }}\right)\end{array}$ & 0.384 & 0 & 0.0486 & 0 & 1 \\
\hline Manager's duality (DUALITY ${ }_{\text {it }}$ ) & 0.078 & 0 & 0.269 & 0 & 1 \\
\hline $\begin{array}{l}\text { Logarithm of managers reward } \\
\left(\text { REWARD }_{\mathrm{it}}\right)\end{array}$ & 2.450 & 0 & 3.340 & 0 & 11.288 \\
\hline $\begin{array}{c}\text { Dummy variable of dividends } \\
\text { (DUMMY_DIV } \\
\text { (DU) }\end{array}$ & 0.963 & 1 & 0.186 & 0 & 1 \\
\hline $\begin{array}{c}\text { Over-investment risk } \\
(\text { OVER_INVESTMENT_ } \\
\left.\text { RISK }_{\text {it }}\right)\end{array}$ & 0.500 & 0.500 & 0.510 & 0 & 1 \\
\hline The size of firm (SIZE $\left.E_{i t}\right)$ & 13.932 & 13.776 & 1.351 & 10.504 & 19.106 \\
\hline QTOBIN criterion $\left(\mathrm{QTOBIN}_{\mathrm{it}}\right)$ & 1.437 & 1.288 & 0.494 & 0.868 & 2.721 \\
\hline $\begin{array}{l}\text { Operating cash flow to asset } \\
\left(\mathrm{CFO}_{\mathrm{it}}\right)\end{array}$ & 0.110 & 0.096 & 0.124 & -0.184 & 0.513 \\
\hline $\begin{array}{l}\text { Operating cash flow variations } \\
\left(\mathrm{CFV}_{\mathrm{it}}\right)\end{array}$ & 0.095 & 0.079 & 0.061 & 0.016 & 0.358 \\
\hline $\begin{array}{l}\text { The ratio of working capital to } \\
\text { asset }\left(\mathrm{NWC}_{\mathrm{it}}\right)\end{array}$ & 0.077 & 0.095 & 0.203 & -0.354 & 0.436 \\
\hline Financial leverage $\left(\mathrm{LEV}_{\text {it }}\right)$ & 0.667 & 0.662 & 0.207 & 0.204 & 1.102 \\
\hline The age of firm (AGE $\left.{ }_{i t}\right)$ & 37.916 & 40 & 12.677 & 11 & 65 \\
\hline
\end{tabular}

Multi-linear regression was used to test the hypotheses in this study. In order to be sure of interpreting regression relations, the hypotheses of a regression were used. The first condition of using this regression is that the error distribution must involve normal distribution with a mean of zero. For this purpose, the Kolmogorov Smirnov test was used. The results of this test showed that the data distribution was normal. Watson-Durbin statistics was used to investigate the lack of autocorrelation function between the independent variables. The value of this statistics is variable between $0-4$. If there is not any correlation between successive residual, then the statistics value should be near 2 . If the statistics value is near zero, then it shows a 
positive correlation between the residual, and if it is near 4, then it shows a negative correlation between the successive residual. Generally, If Watson-Durbin statistics is between 1.5 and 2.5, then the hypothesis including lack of correlation between the model errors can be accepted. Variance inflation factor (VIF) was used to investigate the linear relation between the independent variables. When the variance inflation factor increases, it results in increasing coefficient variances, and it makes regression unsuitable for prediction. The practical experiments demonstrate that if VIF is larger than 5, then there is a probable warning, and if it is larger than 10, then it reminds a serious wearing. This shows that regression coefficients related to multiple linear relations are weakly estimated. When dispersion is near zero, then the higher multi linear correlation exists, and inflation of regression of the standard deviation occurs.

Table 2. Test results of Hausman \& F Limer

\begin{tabular}{|c|c|c|c|c|c|c|c|}
\hline \multicolumn{4}{|c|}{ Chav Test Results } & \multicolumn{3}{c|}{ Hausman Test Results } \\
\hline Model & - & $\begin{array}{c}\text { Statisti } \\
\text { cs }\end{array}$ & $\begin{array}{c}\text { Signifi } \\
\text { cance } \\
\text { level }\end{array}$ & - & $\begin{array}{c}\text { Statisti } \\
\text { cs }\end{array}$ & $\begin{array}{c}\text { Significa } \\
\text { nce } \\
\text { level }\end{array}$ & $\begin{array}{c}\text { Test } \\
\text { Result }\end{array}$ \\
\hline $\begin{array}{c}\text { Research } \\
\text { Model (1) }\end{array}$ & $\begin{array}{c}\text { cross- } \\
\text { section } \\
\text { fixed } \\
\text { effects }\end{array}$ & 1.986 & 0.000 & $\begin{array}{c}\text { cross- } \\
\text { section } \\
\text { random } \\
\text { effects }\end{array}$ & 26.307 & 0.000 & $\begin{array}{c}\text { Polling } \\
\text { method- } \\
\text { fixed } \\
\text { effects }\end{array}$ \\
\hline $\begin{array}{c}\text { Research } \\
\text { Model (2) }\end{array}$ & $\begin{array}{c}\text { cross- } \\
\text { section } \\
\text { fixed } \\
\text { effects }\end{array}$ & 1.737 & 0.000 & $\begin{array}{c}\text { cross- } \\
\text { section } \\
\text { random } \\
\text { effects }\end{array}$ & 22.424 & 0.000 & $\begin{array}{c}\text { Panel } \\
\text { method- } \\
\text { fixed } \\
\text { effects }\end{array}$ \\
\hline
\end{tabular}

In order to select the model of data analysis, data can be considered as series, cross-sectional or panel. Since the data of this research was panel, then it should be specified that whether they were panel or pooling. For this purpose, the Chav test was used, as given in Table 2. The panel method is used for observations where test probability is higher than 5\%, while polling method is used to estimate the model for observations where test probability is less than $5 \%$. The Polling method can be performed by using two models of "fixed effects" and "random effects". In order to determine which model can be used, Hausman test was used. The model of fixed effects was used for observations where test probability is than less $5 \%$, and the model of random was used for observations where test probability is more than $5 \%$. As it was observed, with regard to the obtained level and the significance level accepted as $5 \%$, the results indicate that polling model was used for both models 1 and 2 by considering fixed effects. 
Table 3. Test results of statistical analysis for the first to fourth sub-hypotheses

\begin{tabular}{|c|c|c|c|c|c|}
\hline $\begin{array}{l}\text { Cash }_{\text {it-Cash }} \text { it-1 }=\lambda\left(\text { Cash }_{\text {it }}{ }^{*}-\right. \\
\left.\text { Cash }_{\text {it-1 }}\right) \times \text { Control Variab }\end{array}$ & $\begin{array}{l}\left.\operatorname{Cash}_{\text {it- } 1}\right)+\beta_{1}( \\
e_{i t}+\varepsilon_{i t}\end{array}$ & $\operatorname{Cash}_{\text {it }}{ }^{*}$-Cash & -1) $\times$ Entrench & hent $_{i t}+\beta_{2}(\mathrm{Ca}$ & \\
\hline Depe & ndent variab & e: cash hol & ling adjustme & nts & \\
\hline Variable & Coefficient & $\begin{array}{c}\text { Standard } \\
\text { Error }\end{array}$ & t-statistics & $\begin{array}{c}\text { Significance } \\
\text { level }\end{array}$ & VIF \\
\hline Fixed value & 0.008 & 0.001 & 7.999 & 0.000 & - \\
\hline$\lambda\left(\right.$ Cash $_{\text {it }}{ }^{*}-$ Cash $\left._{\text {it-1 }}\right)$ & -0.0004 & 0.0001 & -2.216 & 0.026 & 1.004 \\
\hline $\begin{array}{l}\left(\operatorname{Cash}_{\mathrm{it}}{ }^{*}-\mathrm{Cash}_{\mathrm{it}-1}\right) \times \\
\text { DUALITY }_{\mathrm{it}}\end{array}$ & -0.045 & 0.109 & -0.417 & 0.676 & 1.266 \\
\hline $\begin{array}{l}\left(\operatorname{Cash}_{\text {it }}{ }^{*}-\mathrm{Cash}_{\mathrm{it}-1}\right) \times \\
\text { REWARD }_{\text {it }}\end{array}$ & 0.023 & 0.009 & 2.629 & 0.008 & 1.797 \\
\hline $\begin{array}{l}\left(\text { Cash }_{\text {it }}{ }^{*}-\mathrm{Cash}_{\text {it- } 1}\right) \times \\
\text { DUMMY_DIV } \\
\text { it }\end{array}$ & 0.065 & 0.136 & 0.483 & 0.629 & 3.029 \\
\hline $\begin{array}{l}\left(\text { Cash }_{\text {it }}{ }^{*}-\text { Cash }_{\text {it-1 }}\right) \times \\
\text { Over_Investment_Risk } \\
\text { it }\end{array}$ & 0.830 & 0.250 & 3.309 & 0.001 & 1.344 \\
\hline $\begin{array}{l}\left(\operatorname{Cash}_{\text {it }}{ }^{*}-\mathrm{Cash}_{\mathrm{it}-1}\right) \times \\
\text { SIZE }_{\text {it }}\end{array}$ & -0.22 & 0.001 & -11.384 & 0.000 & 1.070 \\
\hline $\begin{array}{l}\left(\mathrm{Cash}_{\text {it }}{ }^{*}-\mathrm{Cash}_{\mathrm{it}-1}\right) \times \\
\mathrm{QTOBIN}_{\mathrm{it}}\end{array}$ & 0.078 & 0.048 & 1.615 & 0.106 & 5.387 \\
\hline$\left(\mathrm{Cash}_{\mathrm{it}}{ }^{*}-\mathrm{Cash}_{\mathrm{it}-1}\right) \times \mathrm{CFV}_{\mathrm{it}}$ & -0.039 & 0.099 & -0.390 & 0.695 & 1.052 \\
\hline$\left(\mathrm{Cash}_{\mathrm{it}}{ }^{*}-\mathrm{Cash}_{\mathrm{it}-1}\right) \times \mathrm{NWC}_{\mathrm{it}}$ & 0.106 & 0.170 & 0.623 & 0.533 & 3.092 \\
\hline$\left(\mathrm{Cash}_{\text {it }}{ }^{*}-\mathrm{Cash}_{\mathrm{it}-1}\right) \times \mathrm{LEV}_{\text {it }}$ & 0.311 & 0.140 & 2.214 & 0.027 & 1.229 \\
\hline$\left(\mathrm{Cash}_{\mathrm{it}}{ }^{*}-\mathrm{Cash}_{\mathrm{it}-1}\right) \times \mathrm{AGE}_{\mathrm{it}}$ & 0.001 & 0.002 & 0.502 & 0.615 & 9.969 \\
\hline$R^{2-}$ adjusted coefficient & 0.2 & & $F$ statistics & 30.25 & \\
\hline Durbin-Watson statistics & 2.0 & & $\begin{array}{l}\text { Significance } \\
\text { level }\end{array}$ & 0.000 & \\
\hline
\end{tabular}


Table 4. Test results of statistical analysis for the fifth to eighth sub-hypotheses

\begin{tabular}{|c|c|c|c|c|c|}
\hline \multirow{2}{*}{\multicolumn{6}{|c|}{ 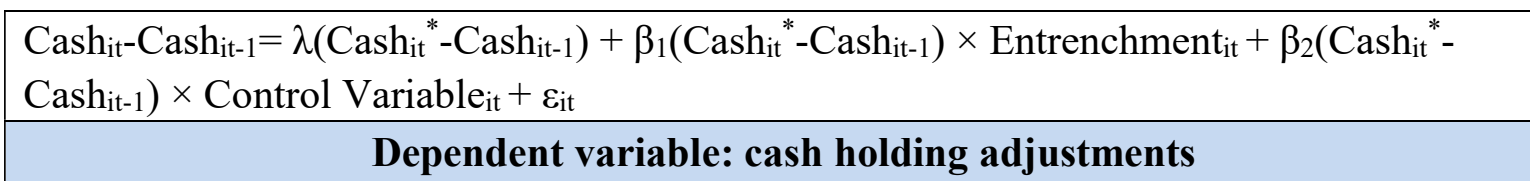 }} \\
\hline & & & & & \\
\hline Variable & & $\begin{array}{l}\text { standard } \\
\text { Error }\end{array}$ & t-statistics & $\begin{array}{c}\text { Significance } \\
\text { level }\end{array}$ & VIF \\
\hline Fixed value & 0.007 & 0.001 & 7.486 & 0.000 & - \\
\hline$\lambda\left(\mathrm{Cash}_{\mathrm{it}}{ }^{*}-\mathrm{Cash}_{\mathrm{it}-1}\right)$ & -0.0003 & 0.0001 & -1.941 & 0.052 & 1.004 \\
\hline $\begin{array}{l}\left(\text { Cash }_{\text {it }}{ }^{*}-\text { Cash }_{\text {it- } 1}\right) \times \\
\text { HighCash }_{\text {it }} \times \text { DUALITY }_{\text {it }}\end{array}$ & 0.087 & 0.192 & 0.455 & 0.649 & 1.474 \\
\hline $\begin{array}{l}\left(\text { Cash }_{\text {it }}{ }^{*}-\text { Cash }_{\text {it- } 1}\right) \times \\
\text { HighCash }_{\text {it }} \times \text { REWARD }_{\text {it }}\end{array}$ & -0.009 & 0.018 & -0.492 & 0.622 & 1.686 \\
\hline $\begin{array}{l}\left(\text { Cash }_{\text {it }}^{*}-\text { Cash }_{\text {it- } 1}\right) \times \\
\text { HighCash }_{\text {it }} \times \\
\text { DUMMY_DIV } \\
\text { it }\end{array}$ & 0.484 & 0.060 & 7.960 & 0.000 & 3.544 \\
\hline $\begin{array}{l}\left(\operatorname{Cash}_{\text {it }}{ }^{*}-\mathrm{Cash}_{\mathrm{it}-1}\right) \times \\
\text { HighCash } \\
\text { it } \times \text { Over- } \\
\text { Investment_Risk }\end{array}$ & 0.449 & 0.586 & 5.880 & 0.000 & 1.328 \\
\hline $\begin{array}{l}\left(\text { Cash }_{\text {it }}{ }^{*}-\mathrm{Cash}_{\text {it- }}\right) \times \\
\text { HighCash }_{\text {it }} \times \text { SIZE }_{\text {it }}\end{array}$ & -0.023 & 0.002 & -11.221 & 0.000 & 1.137 \\
\hline $\begin{array}{l}\left.\text { Cash }_{\text {it }}{ }^{*}-\mathrm{Cash}_{\text {it-1 }}\right) \times \\
\text { HighCash }_{\text {it }} \times \text { QTOBIN }_{\text {it }}\end{array}$ & 0.097 & 0.047 & 2.040 & 0.041 & 4.437 \\
\hline $\begin{array}{l}\left(\text { Cash }_{\text {it }}{ }^{*}-\mathrm{Cash}_{\text {it- }}\right) \times \\
\text { HighCash }_{\text {it }} \times \mathrm{CFV}_{\text {it }}\end{array}$ & -0.029 & 0.097 & -0.305 & 0.760 & 1.051 \\
\hline $\begin{array}{l}\left(\mathrm{Cash}_{\text {it }}{ }^{*}-\mathrm{Cash}_{\text {it-1 }}\right) \times \\
\text { HighCash }_{\text {it }} \times \mathrm{NWC}_{\text {it }}\end{array}$ & 0.278 & 0.158 & 1.763 & 0.078 & 2.592 \\
\hline $\begin{array}{l}\left(\operatorname{Cash}_{\text {it }}{ }^{*}-\mathrm{Cash}_{\mathrm{it}-1}\right) \times \\
\text { HighCash }_{\text {it }} \times \mathrm{LEV}_{\text {it }}\end{array}$ & 0.482 & 0.120 & 3.999 & 0.000 & 60305 \\
\hline $\begin{array}{l}\left(\operatorname{Cash}_{\mathrm{it}}{ }^{*}-\mathrm{Cash}_{\mathrm{it}-1}\right) \times \\
\mathrm{HighCash}_{\mathrm{it}} \times \mathrm{AGE}_{\mathrm{it}}\end{array}$ & 0.003 & 0.001 & 1.610 & 0.107 & 8.085 \\
\hline$R^{2-}$ adjusted coefficient & 0.2 & & $F$ statistics & 29.51 & \\
\hline Durbin-Watson statistics & 2.0 & & $\begin{array}{l}\text { Significance } \\
\text { level }\end{array}$ & 0.000 & \\
\hline
\end{tabular}

\subsection{The first main hypothesis}

In this study, managerial entrenchment was an independent variable. To measure managerial entrenchment, four indices including manager's duality, management reward, cash profit and over-investment risk were used. Hence, we investigate the first main hypothesis through four sub-hypotheses as follows. 
The first sub-hypothesis: in Table 3 , the coefficient of manager's duality [(Cash ${ }_{\mathrm{it}}{ }^{*}-\mathrm{Cash}_{\mathrm{it}}$ $1) \times\left(\right.$ DUALITY $\left.\left._{\mathrm{it}}\right)\right]$ is -0.045 and $t$-statistics is equal to -0.417 . According to the significance level (0.676), there is no significant relationship between the dependent and independent variables. In other words, the manager's duality did not affect cash holding adjustments. Therefore, the first sub-hypothesis can be rejected. It is noted that the results of the first subhypothesis for the studied firms in this work did not match with the results reported by Jiang $\&$ Lie (2016). The main reason is that the manager's duality was low in these firms.

The second sub-hypothesis: the coefficient of management reward [(Cash ${ }^{*}{ }^{*}-\mathrm{Cash}_{\mathrm{it}}$ 1) $\times\left(\right.$ REWARD $\left.\left._{i t}\right)\right]$ was found as 0.023 and t-Statistics was equal to 2.629 (significant in the level of 0.008$)$, as presented in Table 3. Since it is less than the prediction error (1\%), the significance of the independent variable is confirmed in the significance level of $99 \%$. Management reward, as one of the elements of managerial entrenchment, was found to have a positive and significant effect on cash holding adjustments in the studied firms. Therefore, the second sub-hypothesis is confirmed. This finding is in agreement with the results of Jiang \& Lie (2016). The most important reason could be the opportunistic motivation of managers to increase their own reward by increasing cash holdings.

The third sub-hypothesis: the coefficient of dividend payment [(Cash ${ }_{\mathrm{it}}{ }^{*}-\mathrm{Cash}_{\mathrm{it}-}$ 1) $\times($ DUMMY_DIV $i t)]$ was calculated as 0.065 , and $t$-statistics was equal to 0.483 . Based on the significance level obtained as 0.629 , no significant relationship was found between the dependent and independent variables. This indicated that the dividend payment did not affect cash holding adjustments in the studied firms. It can be argued that the reason is because of the requirement forced by the stock exchange that firms are obliged to pay dividends from their cash profit. The firms normally predict the amount of cash profit annually, and the probability of cash holding adjustments to pay dividends is low. The third sub-hypothesis is rejected.

The fourth sub-hypothesis: the coefficient of over-investment risk [(Cash ${ }_{\text {it }}{ }^{*}-\mathrm{Cash}_{\text {it- }}$ 1) $\times\left(\right.$ Over_Investment_Risk $\left.\left.\mathrm{it}_{\mathrm{t}}\right)\right]$ is 0.830 , and t-statistics is equal to 3.309 , with a significance level of 0.001 , as given in Table 3 . The significance of the independent variable was confirmed. In fact, with increasing over-investment risks, the amount of cash holding adjustments increased. This could be because of the opportunistic motivation of managers for overinvestment to increase their rewards. Therefore, the first hypothesis is confirmed in the fourth sub-hypothesis.

Based on the results obtained for the first main hypothesis in this study, it is suggested that decision makers pay special attention to managerial entrenchment in relation to cash holding adjustments. Managers and investors are also recommended to pay attention to managerial entrenchment when they decide about the amount of cash holding adjustments for firms, or when they decide about buying or selling the share of a firm.

\subsection{The second main hypothesis}

The second main hypothesis was studied through the following four sub-hypotheses (fifth to eighth). As mentioned previously, four indices including the manager's duality, management 
reward, cash profit and over-investment risk were used in this research to measure managerial entrenchment.

The fifth sub-hypothesis: the coefficient of the cash holding adjustments variable in the relationship between the managerial entrenchment (manager duality) and cash holding adjustments [( $\left.\left.\mathrm{Cash}_{\mathrm{it}}{ }^{*}-\mathrm{Cash}_{\mathrm{it}-1}\right) \times\left(\mathrm{HighCash}_{\mathrm{it}} \times \mathrm{DUALITY}_{\mathrm{it}}\right)\right]$ was found as 0.067 , and t-Statistics was 0.455 , as presented in Table 4 . Based on the significance level of 0.649 , the moderator variable has no significant direct effect on the correlation between the dependent and independent variables. In fact, cash holding adjustments did not influence the relationship between the manager's duality and cash holding adjustments. Therefore, the fifth hypothesis is rejected. The main reason is that manager duality is low in the Tehran Stock Exchange. The results of the fifth sub-hypothesis do not match with the results reported by Jiang \& Lie (2016).

The sixth sub-hypothesis: the coefficient of cash holding adjustment variable on the relationship between management entrenchment (management rewards and cash holding

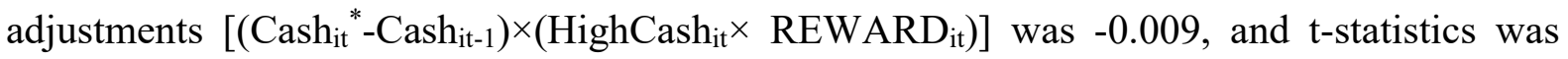
equal to 0.492 (significance level of 0.622 ). The moderator variable has no significant direct effect on the correlation between the dependent and independent variables. Cash holding speed did not affect the relationship between the managers' reward and cash holding adjustments in the studied firms. This was also in agreement with the findings of Jiang \& Lie (2016).

The seventh sub-hypothesis: the coefficient of cash holding adjustments variable on the relationship between management entrenchment dividends, and cash holding adjustments $\left[\left(\mathrm{Cash}_{\text {it }}{ }^{*}{ }^{-}\right.\right.$Cash $\left._{\text {it- } 1}\right) \times$ HighCash $_{\text {it }} \times\left(\right.$ DUMMY_DIV $\left.\left._{\text {it }}\right)\right]$ was obtained as 0.484 (t-statistics 0.960$)$, as given in Table 4 . The results confirmed that cash holding speed can affect the relationship between the dividend and cash holding adjustments. The reason may be the necessity of the stock exchange for the firms to pay dividends. Usually, firms predict this annually, hence, their cash holding speed is higher and they have higher cash holding adjustments. The seventh subhypothesis is confirmed.

The eighth sub-hypothesis: the coefficient of cash holding adjustment variable on the relationship between the management entrenchment (over-investment risk) and cash holding adjustments [( $\left.\mathrm{Cash}_{\mathrm{it}}{ }^{*}-\mathrm{Cash}_{\mathrm{it}-1}\right) \times\left(\mathrm{HighCash}_{\mathrm{it}} \times\right.$ over-Investment_Risk $\left.\left._{\mathrm{it}}\right)\right]$ was 0.449 , and $\mathrm{t}$ statistics was 5.880. The significance of the independent variable was confirmed with a confidence level of $99 \%$. In fact, cash holding speed affected the relationship between the overinvestment risk and cash holding adjustments for the studied firms. The reason could be the opportunistic motivation of the firms' managers for over-investment to increase their rewards. The eighth sub-hypothesis is confirmed and this finding agrees with the evidence reported by Jiang \& Lie (2016).

According to the results found for the second main hypothesis in this work, it is suggested that decision makers pay attention to cash holding speed on the relationship between the effect of managerial entrenchment on cash holding adjustments. Managers and investors are also suggested to pay attention to the effect of cash holding adjustments speed on the relationship between managerial entrenchment and cash holding adjustments when they decide about the 
amount of cash holding adjustments or when they decide about buying or selling shares of a firm.

\section{Conclusions}

This study investigated the relationship between the managerial entrenchment and cash holding adjustments for a sample of 140 firms listed in the Tehran Stock Exchange (TSE) during 2011 to 2016. For managerial entrenchment, four measures of manager's duality, management reward, dividends, and over-investment risk were employed. The concluding remarks are summarized as follows. There is a significant positive relationship between the management rewards and cash holding adjustments. Also, there is a significant positive relationship between the over-investment risk and cash holding adjustments. Cash holding speed was found to have a significant positive effect on the relationship between the dividends and cash holding adjustments. The research findings showed that when managerial entrenchment was used by the over-investment risk, the cash holding speed had a significant positive effect on the relationship between the over-investment risk (managerial entrenchment) and cash holdings adjustments. These results suggest a significant positive relationship between the managerial entrenchment and cash holding adjustments for the studied firms.

\section{References}

AL-Dhamari, R. A., \& Ismail, K. N. I. K. (2014). An Investigation into the Effect of Surplus Free Cash Flow, Corporate Governance and Firm Size on Earnings Predictability. International Journal of Accounting and Information Management, 22(2), 118-133. https://doi.org/10.1108/IJAIM-05-2013-0037

Bates, T. W., Kahle, K. M., \& Stulz, R. (2009). Why do U.S. firms hold so much more cash than they used to?. J. Financ., 64, 1985-2021. https://doi.org/10.1111/j.15406261.2009.01492.x

Dittmar, A. \& Smith, J. (2007). Corporate Governance and the value of Cash Holdings. Journal of Financial Economics, 83(3), 599-634. https://doi.org/10.1016/j.jfineco.2005.12.006

Francis, J., LaFond, R., Olsson, P., \& Schipper, K. (2004). Costs of Equity and Earnings Attributes. Accounting Review, 79, 967-1010. https://doi.org/10.2308/accr.2004.79.4.967

Francis, J., Olsson, P., \& Schipper, K. (2005). Earnings Quality. Foundations and Trends in Accounting, 1(4), 259-340. https://doi.org/10.1561/1400000004

Ferreira, M., \& Vilela, A. (2004). Why do firms fold cash? Evidence from EMU countries. European Financial Management, 10(2), 295-319. https://doi.org/10.1111/j.13547798.2004.00251.x

Gul, F. A. \& Tsui, J. S. L. (2012). Free Cash Flow, Debt-Monitoring, and Audit Pricing: Further Evidence on the Role of Director Equity Ownership. Auditing, 20(2), 71-84. https://doi.org/10.2308/aud.2001.20.2.71 
Habib, A., \& Hasan, M. (2017). Social capital and corporate cash holdings. International Review of Economics \& Finance, 52, 1-20. https://doi.org/10.1016/j.iref.2017.09.005

Harford, J., Mansi S. A., Maxwell, W. F. (2008). Corporate governance and firm cash holdings in the US. Journal of Financial Economics, 87(3), 535-555. https://doi.org/10.1016/j.jfineco.2007.04.002

Jiang, Z., \& Lie, E. (2016). Cash holding adjustments and managerial entrenchment. Journal of Corporate Finance, 36, 190-205. https://doi.org/10.1016/j.jcorpfin.2015.12.008

Jani E., Hoesli M., \& Bender A. (2004). Corporate Cash Holdings and Agency Conflicts. https://doi.org/10.2139/ssrn.563863

Jensen, M. C. (1986). Agency Costs of Free Cash Flow, Corporate Finance, and Takeovers. The American Economic Review, 76(2), 323-329.

Kim, C. S., Mauer, D. C., \& Sherman, A. E. (1998). The Determinants of Corporate Liquidity: Theory and Evidence. Journal of Financial and Quantitative Analysis, 33, 335-359. https://doi.org/10.2307/2331099

Lee, K. W., \& Lee, C. F. (2009). Cash Holdings, Corporate Governance Structure and Firm Valuation. Review of Pacific Basin Financial Markets and Policies, 12(3), 475-508. https://doi.org/10.1142/S021909150900171X

Opler, T., Pinkowitz, L., Stulz, R., \& Williamson, R. (1999). The determinants and implications of corporate cash holdings. Journal of Financial Economics, 52(1), 3-46. https://doi.org/10.1016/S0304-405X(99)00003-3

Ozkan, A., \& Ozkan, N. (2004). Corporate cash holdings: an empirical investigation of UK companies. Journal of Banking and Finance, 28, 2103-2134. https://doi.org/10.1016/j.jbankfin.2003.08.003

Richardson, S. (2006). Over-Investment of Free Cash Flow. Review of Accounting Studies, 11(2), 159-189. https://doi.org/10.1007/s11142-006-9012-1

Locorotondo, R., Dewaelheyns N., \& Hulle, C. V. (2014). Cash holdings and business group membership. Journal of Business Research, 67, 316-323. https://doi.org/10.1016/j.jbusres.2013.01.019

Subramaniam, V., Tang, T. T., Yue, H., \& Zhou, X. (2011). Firm structure and corporate cash $\begin{array}{lllll}\text { holdings. Journal of } \quad \text { Corporate } & \text { Finance, } & \text { 17, } & \text { 759-773. }\end{array}$ https://doi.org/10.1016/j.jcorpfin.2010.06.002

Titman S., \& Wessels R. (1988). The Determinants of Capital Structure Choice. Journal of Finance, 43(1), 1-19. https://doi.org/10.2307/2328319 